\title{
ANALISIS PERKEMBANGAN ANAK USIA 5-6 TAHUN DENGAN METODE DENVER DEVELOPMENT SCREENING TEST MOTORIK KASAR BAGI SISWA TAMAN KANAK-KANAK
}

\author{
Fery Darmanto ${ }^{1 *}$, Cahyo Yuwono ${ }^{2}$, Supriyono ${ }^{3}$, Hermawan Pamot ${ }^{4}$, Rofa Ichsandi $^{5}$ \\ ${ }^{1}$ Jurusan Pendidikan Jasmani Kesehatan dan Rekreasi, Universitas Negeri Semarang, Semarang, Indonesia \\ 2 Jurusan Pendidikan Jasmani Kesehatan dan Rekreasi, Universitas Negeri Semarang, Semarang, Indonesia \\ ${ }^{3}$ Jurusan Pendidikan Jasmani Kesehatan dan Rekreasi, Universitas Negeri Semarang, Semarang, Indonesia \\ ${ }^{4}$ Jurusan Pendidikan Jasmani Kesehatan dan Rekreasi, Universitas Negeri Semarang, Semarang, Indonesia \\ ${ }^{5}$ Jurusan Pendidikan Jasmani Kesehatan dan Rekreasi, Universitas Negeri Semarang, Semarang, Indonesia
}

Fernabil_hok@yahoo.com

(Received: August 2019 / Revised: October 2019 / Accepted: November 2019)

\begin{abstract}
ABSTRAK: Salah satu masa keemasan anak usia dini berada pada usia 0-6 tahun. Usia anak berada pada perkembangan terbaik fisik dan otak. Dalam penelitian ini adalah penelitian kuantitatif dengan menggunakan pendekatan deskriptif. Metode sampling yang digunakan adalah purposive sampling yaitu sebuah teknik pengambilan sampel yang ciri atau karakteristiknya sudah diketahui lebih dulu berdasarkan ciri atau sifat populasi. Kriteria sampel pada penelitian ini anak berusia 5-6 tahun yang terdaftar di TK-B di wilayah kecamatan Gunungpati. Instrumen Penelitian yang digunakan adalah Denver Development Screening Test, metode DDST ini merupakan metode pemantauan perkembangan anak usia 0-6 tahun. Hasil Penelitian didapatkan pada TK-B pada anak usia 5-6 tahun menunjukkan sebagian anak dengan hasil normal sebanyak 220 anak (80,7\%), suspect ada 50 anak (19,3\%). Kesimpulannya adalah keseluruhan aspek perkembangan motorik kasar pada anak pada usia 5-6 di Kecamatan Gunungpati, Semarang adalah normal dan saran sebaiknya orang tua, khususnya ibu dapat memperhatikan perkembangan balitanya selain motorik kasar yaitu stimulasi pada 3 aspek perkembangan personal sosial, adaptif-motorik halus, dan bahasa agar perkembangan anak dapat mencapai optimal

KATA KUNCI: $\quad$ Tes DDST, Motorik Kasar, Anak Usia 5-6 Tahun.
\end{abstract}

ABSTRACTS: One of the golden age of children early age is at the age of 0-6 years. In this study is quantitative research usiang a descriptive approach. The sampling method used was purposive sampling, which is a sampling technique whose characteristics or characteristics are known in advance based on the characteristics of the population. The sample criteria in this study were children aged 5-6 years who were enrolled in tk B Gunungpati sub district. The research instrument used was the denver development screening test. DDST method is a method of monitoring the development of children aged 5-6 years. The results obtained in kindergarten $B$ in children aged 5-6 years showed some children with normal results weere 220 children (80,7\%), there were suspected 50 children $(19,3 \%)$. The conclusion is that all aspects of gross motor development in children aged 5-6 years in gunungpati, semarang sub districts are normal and advice should parents, especially mothers be able to pay attention to their toddler development by stimulating 3 others aspects of development by stimulating 3 others aspects of development, namely personal social aspects, adaptive fine motor skills and languages so that the development of toddlers can achieve optimal.

KEYWORD: $\quad$ DDST test, Gross Motor Skill, Children Aged 5-6 Years.

\section{PENDAHULUAN}

Pembelajaran motorik merupakan suatu rangkaian asosiasi latihan atau pengalaman yang dapat mengubah kemampuan gerak, sebagai contoh bayi yang berusia 3 bulan dengan diberikan bedong hal ini akan menghambat perkembangan motoriknya (Siti Nur, Saka Suminar, 2017). Pada anak usia dini keterampilan 
fisik yang dibutuhkan adalah aktivitas yang bisa dipelajari, dilatih khususnya pada model dan metode yang digunakan pada masa awal perkembangan, karena anak usia dini dikenal sebagai periode "kritis" untuk pengembangan dan keterampilan gerak dasar (Arzu Ozyurek, Isa Ozkan, Zuhal Bedge, N. Ferah Yavuz, 2015), sehingga begitu pentingnya perkembangan motorik anak yang dipergunakan pada aktivitas yang berhubungan dengan lingkungan maupun orang-orang sekitarnya baik fisik, sosial maupun bahasa. Pada masa anak usia dini, setiap individu mengalami proses pertumbuhan dan perkembangan yang sangat pesat, hal ini diaplikasikan dalam kegiatan sehari-hari seperti melakukan bergerak dengan berlari dihalaman dan cara berbaris dalam sebuah ruangan (Ladru Danielle Ekman, Gustafon Katarina, 2018). Hal ini dikuatkan dalam sebuah penelitian (Brianne $A$ Brujins, Kristi B Adamo, Shauna M. Burke, etc, 2019) anak yang melakukan aktivitas fisik dapat menentukan kepercayaan diri, respon positif dan memfasilitasi kegiatan yang mempengaruhi kesehatannya. Artinya anak yang melakukan aktifitas fisik mendapatkan dampak yang positif bagi psikologis dan kesehatan dalam kehidupannya. Pada anak usia dini yang berusia 06 tahun merupakan rentang usia yang sangat berharga dibandingkan dengan usia selanjutnya karena perkembangan kecerdasannya tumbuh sangat luar biasa, berdasarkan hasil review pada buku dan artikel perkembangan motorik usia 0-6 masa ini disebut dengan usia emas atau "Golden Age". Golden Age ini hanya datang sekali dan tidak dapat diulangi lagi. Ini dikatakan sangat penting pada anak yang menginjak usia 3 tahun berjalan karena anak pada usia ini sudah mempunyai kompetensi ketrampilan gerak. Dengan mengenal hal-hal di atas, Maka kita sebagai orang tua atau guru mengetahui kemampuan, kebutuhan dan pengalaman belajar gerak, yang berhubungan dengan usia anak sehingga perkembangan motorik anak lebih optimal dan mendapatkan pengalaman gerak yang sesuai.

Penggunaan DDST II merupakan pengembangan yang dimulai sejak tahun 1967 yang dikenal dengan Denver Development Materials atau "Denver Scale" yang dibuat di University of Colorado Medical Center di Denver,
Colorado oleh Willian K Frankenburd dan J. B Dodds (dalam Heru Santoso, 2013).

Dalam penggunaan skrining ini sangat mudah berdasarkan tabel yang sudah di tetapkan berdasarkan usia dan kebutuhan personal yang akan diketahui perkembangan anak yang dapat diidentifikasi sejak awal. Hal ini diperkuat oleh beberapa penelitian yang dilakukan di Brazil dengan tujuan mengidentifikasi tentang perkembangan neuropsikomotor anak yang lahir prematur (Solange Raydan Rocha, Lílian de Fátima Dornelas, Lívia de Castro Magalhães, 2013), yang kedua dengan menggunakan skrinning Denver II dapat dilakukan analisis keterampilan mendengar, bahasa, motorik dan sosial pada anak usia prasekolah. Pada hasil penelitian sebelumnya DDST II dapat mengetahui perkembangan fisik khususnya pada anak pra sekolah yang mempunyai masalah dengan anemia dan kelebihan berat badan.

Dari hasil review literatur yang dilakukan penulis dengan melihat pada jurnal, hasil riset mencermati bahwasannya untuk penelitian pemantauan perkembangan anak belum dilakukan khususnya TK diwilayah Kecamatan Gunungpati. Berdasarkan latar belakang dan review literatur di atas, betapa pentingnya penelitian ini dilakukan yang memfokuskan khususnya dalam perkembangan motorik kasar pada anak usia 5-6 tahun dengan menggunakan metode Denver Development Screening Test (DDST), khususnya pada siswa TK B usia 5-6 tahun di kecamatan Gunungpati, Kota Semarang. Dengan skrining ini diharapkan dapat mengidentifikasi keterlambatan dalam perkembangan anak dan harus ditangani sedini mungkin.

\section{METODE PENELITIAN}

Jenis penelitian yang digunakan dalam penelitian ini adalah penelitian kuantitatif dengan menggunakan pendekatan deskriptif. Dalam penelitian memfokuskan pada perkembangan motorik kasar pada anak usia 5-6 tahun dengan menggunakan metode DDST.

Lokasi penelitian ini berada di Kecamatan Gunungpati, Kota Semarang, dimana lokasi ini merupakan dataran tinggi. Gunungpati merupakan daerah perbukitan, wilayah Gunungpati Barat dengan ketinggian 259,00 
MDPL, dan wilayah Gunungpati timur dengan ketinggian 348,00 MDPL. (BPS Kota Semarang)

Metode sampling yang digunakan dalam penelitian ini adalah Purposive Sampling atau sampel bertujuan adalah sebuah teknik pengambilan sampel yang ciri atau karakteristiknya sudah diketahui lebih dulu berdasarkan ciri atau sifat populasi (Maksum 2012:60). Kriteria sampel pada penelitian ini berusia 5-6 tahun yang terdaftar di TK-B di wilayah kecamatan Gunungpati yang sesuai dengan tujuan penelitian.

Instrumen penelitian DDST digunakan hanya memfokuskan pada motorik kasar anak usia 5-6 tahun yang terdiri dari gerakan, yaitu: (1) Berdiri 1 kaki selama 4 detik; (2) Berdiri 1 kaki selama 5 detik; (3) Berjalan lurus dengan meluruskan tumit sejauh 8 langkah; (4) Berdiri 1 kaki selama 6 detik. Untuk pemberian skor setiap item dengan ketentuan, sebagai berikut:

Tabel 1. Keterangan Skor pada Item Tes

\begin{tabular}{|c|c|c|c|}
\hline No. & Uraian & Keterangan & Nila \\
\hline 1 & $\mathrm{~L}$ & Lulus & 2 \\
\hline 2 & G & Gagal & 1 \\
\hline 3 & $M$ & Menolak & 0 \\
\hline
\end{tabular}

intrepretasi dikategorikan menjadi 3 yaitu,

"Normal", "Suspek", dan "Tak dapat diuji".

Berikut penjelasan mengenai ketiga kategori tersebut adalah, sebagai berikut:

a. Normal diberikan apabila tidak ada skor "terlambat" (0 T) dan atau maksimal 1 (1 P)

b. Suspek diberikan apabila jika satu atau lebih skor "Terlambat" (1 T) dan atau lebih "Peringatan". Ingat dalam hal ini $T$ dan $P$ harus disebabkan oleh kegagalan (G) bukan oleh penolakan (M). hal ini terjadi karena faktor sesaat, seperti rasa takut, sakit atau kelelahan.

c. Tidak dapat diuji diberikan Interpretasi "Tidak Dapat Diuji" jika terdapat satu atau lebih skor "Terlambat" (1 T) dan atau dua atau lebih "Peringatan" (2 P). Dalam hal ini T dan $\mathrm{P}$ harus disebabkan oleh penolakan (M) bukan kegagalan (G). Jika hasil ini didapat, Maka diulang dalam 1-2 minggu mendatang.

\section{HASIL}

Tabel 2. Daftar Subjek Penelitian

\begin{tabular}{clcc}
\hline No. & \multicolumn{1}{c}{ Nama TK } & $\begin{array}{c}\text { Jumlah } \\
\text { Siswa }\end{array}$ & $\begin{array}{c}\text { Jumlah Siswa } \\
\text { yang masuk }\end{array}$ \\
\hline 1 & TK Qurrotul Aini & 14 & 10 \\
\hline 2 & TK Pertiwi 45 & 42 & 37 \\
\hline 3 & TK Al-Jannah & 45 & 41 \\
\hline 4 & TK Pertiwi 44 & 35 & 29 \\
\hline 5 & TK Pertiwi 49 & 21 & 14 \\
\hline 6 & TK Sekar Mekar & 25 & 18 \\
\hline 7 & TK ABA 52 & 42 & 31 \\
\hline 8 & TK ABA 38 & 63 & 56 \\
\hline 9 & TK IT Sekar Gading & 32 & 0 \\
\hline & Total & 313 & 236 \\
\hline & & &
\end{tabular}

Tabel 3. Hasil Analisis Tes DDST II TK Qurrotul Aini

\begin{tabular}{|c|c|c|c|c|}
\hline \multicolumn{5}{|c|}{$\begin{array}{l}\text { Hasil Analisis Tes DDST II Sektor Motorik Kasar Anak Usia } \\
\text { 5-6 Tahun }\end{array}$} \\
\hline $\begin{array}{c}\text { Jenis } \\
\text { Tes }\end{array}$ & $\begin{array}{c}\text { Hasil } \\
\text { Intrepretasi }\end{array}$ & Frekuensi & Prosentase & $\begin{array}{l}\text { Kumulatif } \\
\text { Prosentase }\end{array}$ \\
\hline $\begin{array}{l}\text { Tidak } \\
\text { Masuk } \\
\text { Sekolah }\end{array}$ & & 4 & 28,6 & 28,6 \\
\hline \multirow{4}{*}{$\begin{array}{c}\text { Berdiri } \\
\text { satu } \\
\text { kaki } 4 \\
\text { detik }\end{array}$} & Normal & 10 & 71,4 & 100,0 \\
\hline & Suspect & - & - & - \\
\hline & Untestable & - & - & - \\
\hline & Total & 10 & 71,4 & 100,0 \\
\hline \multirow{4}{*}{$\begin{array}{c}\text { Berdiri } \\
\text { satu } \\
\text { kaki } 5 \\
\text { detik }\end{array}$} & Normal & 10 & 71,4 & 100,0 \\
\hline & Suspect & - & - & - \\
\hline & Untestable & - & - & - \\
\hline & Total & 10 & 71,4 & 100,0 \\
\hline \multirow{4}{*}{$\begin{array}{c}\text { Berjalan } \\
\text { tumit } \\
\text { ke jari } \\
\text { kaki }\end{array}$} & Normal & 10 & 71,4 & 100,0 \\
\hline & Suspect & - & - & - \\
\hline & Untestable & - & - & - \\
\hline & Total & 10 & 71,4 & 100,0 \\
\hline \multirow{4}{*}{$\begin{array}{c}\text { Berdiri } \\
\text { satu } \\
\text { kaki } 6 \\
\text { detik }\end{array}$} & Normal & 10 & 71,4 & 100,0 \\
\hline & Suspect & - & - & - \\
\hline & Untestable & - & - & - \\
\hline & Total & 14 & 71,4 & 100,0 \\
\hline
\end{tabular}

TK Qurrotul Aini tidak ditemukan suspect dan untestable, Maka dinyatakan anak dalam batas normal dan tidak mengalami keterlambatan dalam perkembangan motorik kasar

Tabel 4. Hasil Analisis Tes DDST II TK Pertiwi 45

\begin{tabular}{ccccc}
\hline \multicolumn{5}{c}{ Hasil Analisis Tes DDST II Sektor Motorik Kasar Anak Usia } \\
5-6 Tahun \\
\hline $\begin{array}{c}\text { Jenis } \\
\text { Tes }\end{array}$ & $\begin{array}{c}\text { Hasil } \\
\text { Intrepretasi }\end{array}$ & Frekuensi & Prosentase & $\begin{array}{c}\text { Kumulatif } \\
\text { Prosentase }\end{array}$ \\
\hline $\begin{array}{c}\text { Tidak } \\
\text { Masuk } \\
\text { Sekolah }\end{array}$ & & 5 & 11,9 & 11,9 \\
\hline $\begin{array}{c}\text { Berdiri } \\
\text { satu } \\
\text { kaki } 4 \\
\text { detik }\end{array}$ & Normal & 33 & $\mathbf{7 8 , 6}$ & 100,0 \\
\cline { 2 - 5 } & Suspect & 4 & 9,5 & 21,4 \\
\hline Bntestable & - & - & - \\
\hline Berdiri & Notal & $\mathbf{4 2}$ & $\mathbf{8 8 , 1}$ & \\
\hline & Normal & 33 & $\mathbf{7 8 , 6}$ & 100,0 \\
\hline
\end{tabular}


Journal of Sport and Exercise Science, Vol 2, No 2, 2019 (38-43)

Analisis Perkembangan Anak Usia 5-6 Tahun dengan Metode Devender Development Screening Test Motorik Kasar bagi Siswa Taman Kanak-Kanak

\begin{tabular}{|c|c|c|c|c|}
\hline \multirow{3}{*}{$\begin{array}{c}\text { satu } \\
\text { kaki } 5 \\
\text { detik }\end{array}$} & Suspect & 4 & 9,5 & 21,4 \\
\hline & Untestable & - & - & - \\
\hline & Total & 37 & 100,0 & \\
\hline \multirow{4}{*}{$\begin{array}{c}\text { Berjalan } \\
\text { tumit } \\
\text { ke jari } \\
\text { kaki }\end{array}$} & Normal & 36 & 85,7 & 100,0 \\
\hline & Suspect & 1 & 2,4 & 14,3 \\
\hline & Untestable & - & & \\
\hline & Total & 37 & 88,1 & \\
\hline \multirow{4}{*}{$\begin{array}{l}\text { Berdiri } \\
\text { satu } \\
\text { kaki } 6 \\
\text { detik }\end{array}$} & Normal & 31 & 73,8 & 100,0 \\
\hline & Suspect & 6 & 14,3 & 26,2 \\
\hline & Untestable & - & - & - \\
\hline & Total & 37 & 88,1 & \\
\hline
\end{tabular}

TK Pertiwi 45 ditemukan suspect pada beberapa tes yaitu tes berdiri 1 kaki selama 4 detik, sebanyak 4 anak, tes berdiri 5 detik, sebanyak 4 anak, tes berjalan tumit ke jari kaki sebanyak 1 anak dan tes berdiri 1 kaki 6 detik sebanyak 6 anak serta tidak ada yang menolak ketika melakukan tes ini. Untestable. Hal ini biasanya anak tegang atau pertama kali melakukan tes ini, tetapi ketika diulang anak bisa melakukan tes tersebut. Maka dinyatakan siswa pada TK Pertiwi 45 dalam batas normal dan tidak mengalami keterlambatan dalam perkembangan motorik kasar

Tabel 5. Hasil Analisis Tes DDST II TK Al-Jannah

\begin{tabular}{|c|c|c|c|c|}
\hline \multicolumn{5}{|c|}{$\begin{array}{l}\text { Hasil Analisis Tes DDST II Sektor Motorik Kasar Anak Usia } \\
\text { 5-6 Tahun }\end{array}$} \\
\hline $\begin{array}{l}\text { Jenis } \\
\text { Tes }\end{array}$ & $\begin{array}{c}\text { Hasil } \\
\text { Intrepretasi }\end{array}$ & Frekuensi & Prosentase & $\begin{array}{l}\text { Kumulatif } \\
\text { Prosentase }\end{array}$ \\
\hline $\begin{array}{l}\text { Tidak } \\
\text { Masuk } \\
\text { Sekolah }\end{array}$ & & 4 & 9,8 & 9,8 \\
\hline \multirow{4}{*}{$\begin{array}{l}\text { Berdiri } \\
\text { satu } \\
\text { kaki } 4 \\
\text { detik }\end{array}$} & Normal & 33 & 80,5 & 100,0 \\
\hline & Suspect & 4 & 9,8 & 19,5 \\
\hline & Untestable & - & - & \\
\hline & Total & 37 & 90,2 & \\
\hline \multirow{4}{*}{$\begin{array}{l}\text { Berdiri } \\
\text { satu } \\
\text { kaki } 5 \\
\text { detik }\end{array}$} & Normal & 37 & 90,2 & 100,0 \\
\hline & Suspect & - & - & - \\
\hline & Untestable & - & - & - \\
\hline & Total & 37 & 90,2 & \\
\hline \multirow{4}{*}{$\begin{array}{c}\text { Berjalan } \\
\text { tumit } \\
\text { ke jari } \\
\text { kaki }\end{array}$} & Normal & 37 & 90,2 & 100,0 \\
\hline & Suspect & - & - & - \\
\hline & Untestable & - & - & - \\
\hline & Total & 37 & 90,2 & \\
\hline \multirow{4}{*}{$\begin{array}{c}\text { Berdiri } \\
\text { satu } \\
\text { kaki } 6 \\
\text { detik }\end{array}$} & Normal & 33 & 80,5 & 100,0 \\
\hline & Suspect & 3 & 7,3 & 19,5 \\
\hline & Untestable & 1 & 2,4 & - \\
\hline & Total & 37 & 90,2 & \\
\hline
\end{tabular}

TK Pertiwi 45 ditemukan suspect pada beberapa tes yaitu tes berdiri 1 kaki selama 4 detik sebanyak 4 anak, dan tes berdiri 1 kaki selama 6 detik, sebanyak 6 anak serta tidak ada yang menolak ketika melakukan tes ini. Untestable. Hal ini biasanya anak tegang atau pertama kali melakukan tes ini, tetapi ketika diulang anak bisa melakukan tes tersebut. Maka dinyatakan siswa pada TK Pertiwi 45 dalam batas normal dan tidak mengalami keterlambatan dalam perkembangan motorik kasar

Tabel 6. Hasil Analisis Tes DDST II TK Pertiwi 44

\begin{tabular}{ccccc}
\hline \multicolumn{4}{c}{ Hasil Analisis Tes DDST II Sektor Motorik Kasar Anak Usia } \\
5-6 Tahun
\end{tabular}

\begin{tabular}{|c|c|c|c|c|}
\hline Sekolah & & & & \\
\hline \multirow{4}{*}{$\begin{array}{c}\text { Berdiri } \\
\text { satu } \\
\text { kaki } 4 \\
\text { detik }\end{array}$} & Normal & 26 & 74,3 & 100,0 \\
\hline & Suspect & 3 & 8,6 & 25,7 \\
\hline & Untestable & - & - & - \\
\hline & Total & 29 & 82,9 & - \\
\hline \multirow{4}{*}{$\begin{array}{c}\text { Berdiri } \\
\text { satu } \\
\text { kaki } 5 \\
\text { detik }\end{array}$} & Normal & 27 & 77,1 & 100,0 \\
\hline & Suspect & 2 & 5,7 & 22,9 \\
\hline & Untestable & - & - & - \\
\hline & Total & 29 & 82,9 & - \\
\hline \multirow{4}{*}{$\begin{array}{c}\text { Berjalan } \\
\text { tumit } \\
\text { ke jari } \\
\text { kaki }\end{array}$} & Normal & 28 & 80,0 & 100,0 \\
\hline & Suspect & 1 & 2,9 & 22,9 \\
\hline & Untestable & - & - & - \\
\hline & Total & 29 & 82,9 & - \\
\hline \multirow{4}{*}{$\begin{array}{c}\text { Berdiri } \\
\text { satu } \\
\text { kaki } 6 \\
\text { detik }\end{array}$} & Normal & 26 & 74,3 & 100,0 \\
\hline & Suspect & 3 & 8,6 & 25,7 \\
\hline & Untestable & - & - & - \\
\hline & Total & 29 & 82,9 & \\
\hline
\end{tabular}

TK Pertiwi 44 ditemukan suspect pada beberapa tes yaitu tes berdiri 1 kaki selama 4 detik sebanyak 3 anak, tes berdiri 1 kaki 5 detik sebanyak 2 anak dan tes berdiri 1 kaki selama 6 detik, sebanyak 3 anak serta tidak ada yang untastable atau menolak ketika melakukan tes ini. Hal ini biasanya anak tegang atau pertama kali melakukan tes ini, tetapi ketika diulang anak bisa melakukan tes tersebut. Maka dinyatakan siswa pada TK Pertiwi 44 dalam batas normal dan tidak mengalami keterlambatan dalam perkembangan motorik kasar

Tabel 7. Hasil Analisis Tes DDST II TK ABA 52

\begin{tabular}{|c|c|c|c|c|}
\hline \multicolumn{5}{|c|}{$\begin{array}{l}\text { Hasil Analisis Tes DDST II Sektor Motorik Kasar Anak Usia } \\
\text { 5-6 Tahun }\end{array}$} \\
\hline $\begin{array}{c}\text { Jenis } \\
\text { Tes }\end{array}$ & $\begin{array}{c}\text { Hasil } \\
\text { Intrepretasi }\end{array}$ & Frekuensi & Prosentase & $\begin{array}{l}\text { Kumulatif } \\
\text { Prosentase }\end{array}$ \\
\hline $\begin{array}{l}\text { Tidak } \\
\text { Masuk } \\
\text { Sekolah }\end{array}$ & & 11 & 26,2 & 26,2 \\
\hline \multirow{4}{*}{$\begin{array}{c}\text { Berdiri } \\
\text { satu } \\
\text { kaki } 4 \\
\text { detik }\end{array}$} & Normal & 27 & 64,3 & 35,7 \\
\hline & Suspect & 4 & 9,5 & 100,0 \\
\hline & Untestable & - & - & - \\
\hline & Total & 31 & 73,8 & \\
\hline \multirow{4}{*}{$\begin{array}{c}\text { Berdiri } \\
\text { satu } \\
\text { kaki } 5 \\
\text { detik }\end{array}$} & Normal & 25 & 59,5 & 100,0 \\
\hline & Suspect & 6 & 14,3 & 40,5 \\
\hline & Untestable & - & - & \\
\hline & Total & 31 & 73,8 & \\
\hline \multirow{4}{*}{$\begin{array}{c}\text { Berjalan } \\
\text { tumit } \\
\text { ke jari } \\
\text { kaki }\end{array}$} & Normal & 28 & 66,7 & 100,0 \\
\hline & Suspect & 3 & 7,1 & 33,3 \\
\hline & Untestable & - & - & \\
\hline & Total & 31 & 73,8 & \\
\hline \multirow{4}{*}{$\begin{array}{c}\text { Berdiri } \\
\text { satu } \\
\text { kaki } 6 \\
\text { detik }\end{array}$} & Normal & 24 & 57,1 & 100,0 \\
\hline & Suspect & 7 & 16,7 & 42,8 \\
\hline & Untestable & - & - & \\
\hline & Total & 31 & 73,8 & \\
\hline
\end{tabular}

TK ABA 52 ditemukan suspect pada beberapa tes yaitu tes berdiri 1 kaki 4 detik sebanyak 4 anak, tes berdiri 1 kaki 5 detik sebanyak 6 anak, berjalan tumit ke jari kaki sebanyak 3 anak dan tes berdiri 1 kaki 6 detik, sebanyak 7 anak serta tidak ada yang untastable atau menolak ketika melakukan tes ini. Hal ini biasanya anak tegang atau pertama kali melakukan tes ini, tetapi ketika diulang anak bisa melakukan tes tersebut. Maka dinyatakan siswa pada TK ABA 52 dalam batas normal dan tidak mengalami keterlambatan dalam perkembangan motorik kasar 
Tabel 8. Hasil Analisis Tes DDST II TK ABA 38 Hasil Analisis Tes DDST II Sektor Motorik Kasar Anak Usia 5-6 Tahun

\begin{tabular}{|c|c|c|c|c|}
\hline $\begin{array}{c}\text { Jenis } \\
\text { Tes }\end{array}$ & $\begin{array}{c}\text { Hasil } \\
\text { Intrepretasi }\end{array}$ & Frekuensi & Prosentase & $\begin{array}{c}\text { Kumulatif } \\
\text { Prosentase }\end{array}$ \\
\hline \multicolumn{5}{|l|}{ Tidak } \\
\hline \multirow{2}{*}{\multicolumn{5}{|c|}{$\begin{array}{l}\text { Masuk } \\
\text { Sekolah }\end{array}$}} \\
\hline & & & & \\
\hline \multirow{4}{*}{$\begin{array}{c}\text { Berdiri } \\
\text { satu } \\
\text { kaki } 4 \\
\text { detik }\end{array}$} & Normal & 54 & 87,1 & 100,0 \\
\hline & Suspect & 1 & 1,6 & 12,9 \\
\hline & Untestable & - & - & - \\
\hline & Total & 55 & 88,7 & \\
\hline \multirow{4}{*}{$\begin{array}{c}\text { Berdiri } \\
\text { satu } \\
\text { kaki } 5 \\
\text { detik }\end{array}$} & Normal & 52 & 83,9 & 100,0 \\
\hline & Suspect & 3 & 4,8 & 16,1 \\
\hline & Untestable & - & - & - \\
\hline & Total & 55 & 88,7 & \\
\hline \multirow{4}{*}{$\begin{array}{c}\text { Berjalan } \\
\text { tumit } \\
\text { ke jari } \\
\text { kaki }\end{array}$} & Normal & 53 & 85,5 & 100,0 \\
\hline & Suspect & 2 & 3,2 & 14,5 \\
\hline & Untestable & - & - & - \\
\hline & Total & 55 & 88,7 & \\
\hline \multirow{4}{*}{$\begin{array}{c}\text { Berdiri } \\
\text { satu } \\
\text { kaki } 6 \\
\text { detik }\end{array}$} & Normal & 52 & 83,9 & 100,0 \\
\hline & Suspect & 3 & 4,8 & 16,1 \\
\hline & Untestable & - & - & - \\
\hline & Total & 55 & 88,7 & \\
\hline \multicolumn{5}{|c|}{$\begin{array}{l}\text { TK ABA } 38 \text { ditemukan suspect pada beberapa tes yaitu tes berdiri } \\
1 \text { kaki } 4 \text { detik sebanyak } 1 \text { anak, tes berdiri } 1 \text { kaki } 5 \text { detik sebanyak } \\
3 \text { anak, berjalan tumit ke jari kaki sebanyak } 2 \text { anak dan tes berdiri } \\
1 \text { kaki } 6 \text { detik, sebanyak } 3 \text { anak serta tidak ada yang untastable } \\
\text { atau menolak ketika melakukan tes ini. Hal ini biasanya anak } \\
\text { tegang atau pertama kali melakukan tes ini, tetapi ketika diulang } \\
\text { anak bisa melakukan tes tersebut. Maka dinyatakan siswa pada TK } \\
\text { ABA } 52 \text { dalam batas normal dan tidak mengalami keterlambatan } \\
\text { dalam perkembangan motorik kasar }\end{array}$} \\
\hline
\end{tabular}

Tabel 9. Hasil Analisis Tes DDST II TK Sekar Gading Hasil Analisis Tes DDST II Sektor Motorik Kasar Anak Usia 5-6 Tahun

\begin{tabular}{|c|c|c|c|c|}
\hline $\begin{array}{l}\text { Jenis } \\
\text { Tes }\end{array}$ & $\begin{array}{c}\text { Hasil } \\
\text { Intrepretasi }\end{array}$ & Frekuensi & Prosentase & $\begin{array}{l}\text { Kumulatif } \\
\text { Prosentase }\end{array}$ \\
\hline \multicolumn{5}{|l|}{ Tidak } \\
\hline $\begin{array}{c}\text { Masuk } \\
\text { Sekolah }\end{array}$ & & 3 & 9,4 & 9,4 \\
\hline \multirow{4}{*}{$\begin{array}{c}\text { Berdiri } \\
\text { satu } \\
\text { kaki } 4 \\
\text { detik }\end{array}$} & Normal & 28 & 87,5 & 100,0 \\
\hline & Suspect & 1 & 3,1 & 12,5 \\
\hline & Untestable & - & - & - \\
\hline & Total & 29 & 90,6 & \\
\hline \multirow{4}{*}{$\begin{array}{c}\text { Berdiri } \\
\text { satu } \\
\text { kaki } 5 \\
\text { detik }\end{array}$} & Normal & 26 & 81,3 & 100,0 \\
\hline & Suspect & 3 & 9,4 & 18,8 \\
\hline & Untestable & - & - & - \\
\hline & Total & 29 & 90,6 & \\
\hline \multirow{4}{*}{$\begin{array}{c}\text { Berjalan } \\
\text { tumit } \\
\text { ke jari } \\
\text { kaki }\end{array}$} & Normal & 25 & 78,1 & 100,0 \\
\hline & Suspect & 4 & 12,5 & 21,9 \\
\hline & Untestable & - & - & - \\
\hline & Total & 29 & 90,6 & \\
\hline \multirow{4}{*}{$\begin{array}{c}\text { Berdiri } \\
\text { satu } \\
\text { kaki } 6 \\
\text { detik }\end{array}$} & Normal & 25 & 78,1 & 100,0 \\
\hline & Suspect & 4 & 12,5 & 21,9 \\
\hline & Untestable & - & - & \\
\hline & Total & 29 & 90,6 & \\
\hline
\end{tabular}

TK IT Sekar Gading ditemukan suspect pada beberapa tes yaitu tes berdiri 1 kaki 4 detik sebanyak 1 anak, tes berdiri 1 kaki 5 detik sebanyak 3 anak, berjalan tumit ke jari kaki sebanyak 4 anak dan tes berdiri 1 kaki 6 detik, sebanyak 4 anak serta tidak ada yang untastable atau menolak ketika melakukan tes ini. Hal ini biasanya anak tegang atau pertama kali melakukan tes ini, tetapi ketika diulang anak bisa melakukan tes tersebut. Maka dinyatakan siswa pada TK IT sekar Gading dalam batas normal dan tidak mengalami keterlambatan dalam perkembangan motorik kasar.

Dari 9 TK yang menjadi sampel penelitian sebanyak 260 siswa mengikuti tes DDST II yang dilakukan oleh peneliti dan sebanyak 54 siswa tidak masuk, Hal ini ketika mengambil data bertepatan dengan bulan Ramadhan dimana pembelajaran hanya dilakukan 2 saja dan ketika saat itu banyak TK yang sudah mengakhiri kegiatan pembelajaran pada semester 2 dan hanya kegiatan yang bersifat mengulang saja.

Dari data di atas, dapat disimpulkan bahwasannya hasil dari keseluruhan tes DDST II yang telah dilakukan oleh peneliti terdapat beberapa indikasi anak mengalami gangguan perkembangan.

Berikut adalah diagram keseluruhan data yang yang menjelaskan sebanyak 50 anak berada pada suspect dan sebanyak 210 telah dinyatakan normal. Hal ini dapat dilihat pada diagram dibawah ini:

\section{Tes DDST II}

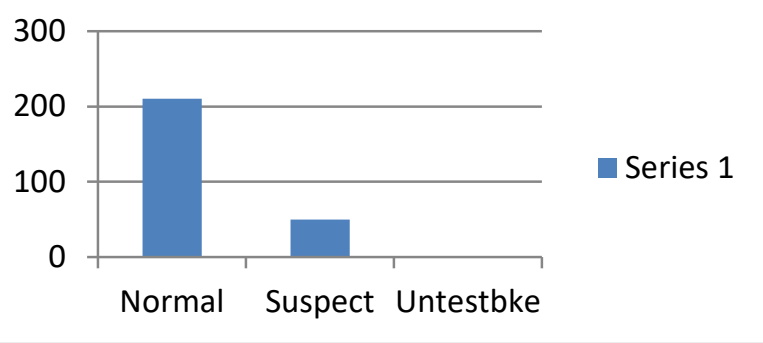

Grafik 1. Data Keseluruhan Tes DDST II

\section{PEMBAHASAN}

Berdasarkan hasil penelitian, menunjukkan bahwa perkembangan siswa yang diukur menggunakan DDST II pada aspek motorik kasar, didapatkan penilaian keseluruhan perkembangan seluruh anak usia 5-6 tahun pada TK-B pada tabel $B$ yang menunjukkan dengan hasil normal sebanyak 220 anak (80,7\%), suspect ada 50 anak $(19,3 \%)$. Hal tersebut menunjukkan secara keseluruhan anak usia 5-6 tahun di Kecamatan Gunungpati memiliki perkembangan yang baik. Namun hal ini peran lingkungan keluarga, sekolah sebagai lembaga pendidikan harus bisa memberikan stimulasi dan memantau perkembangannnya pada puskesmas atau 
semacam lembaga yang disediakan pemerintah untuk tumbuh kembang anak.

Pada penelitian ini juga ditemukan ada 2 anak yang mengalami perkembangan abnormal. Satu anak anak mengalami keterlambatan (delay) pada perkembangan motorik kasarnya, untuk penyebabnya saat pengambilan data guru pada siswa tersebut sudah memberitahu bahwasannya ada 1 anak ABK dan penyebabnya peneliti tidak menggali lebih dalam lagi kemudian anak yang mengalami perkembangan meragukan (suspect) disebabkan anak gagal dalam melakukan tes atau mengulang hal ini dikarenakan anak kurang konsentrasi, atau sebab lain peran lingkungan atau keluarga kurang teratur dalam memberikan stimulasi. Anak dengan hasil perkembangan sesuai dapat melanjutkan stimulasi sesuai dengan tahapan perkembanganya, anak dengan hasil meragukan (suspect) dapat melakukan uji ulang dalam 1-2 minggu untuk menghilangkan faktor sesaat (takut, lelah, sakit, tidak nyaman), anak dengan perkembangan tidak teruji melakukan ulang pemeriksaan 1-2 minggu.

\section{SIMPULAN DAN REKOMENDASI}

Hasil kesimpulan keseluruhan aspek perkembangan pada anak menggunakan metode DDST II didapatkan perkembangan anak anak pada usia 5-6 di Kecamatan Gunungpati, Semarang adalah normal dan sebaiknya orang tua, khususnya ibu dapat memperhatikan perkembangan balitanya dengan cara menstimulasi pada 4 aspek perkembangan, yaitu personal sosial, adaptif-motorik halus, bahasa, dan motorik kasar agar perkembangan balita dapat mencapai optimal.

Rekomendasi dari penelitian ini perlunya sekolah dan orang tua melakukan sinergi atau kerjasama dalam hal tumbuh kembang anak hal ini untuk meningkatkan manusia Indonesia yang unggul dan berkarakter di masa depan yang dimulai sejak dini.

\section{REFERENSI}

Arikunto. (2010). Prosedur Penelitian Suatu Pendekatan Praktik. Jakarta: RINEKA CIPTA

Arzu Özyürek, Isa Özkan, Zuhal Begde, N. Ferah Yavuz. (2015). Physical Education And Sports In Preschool Period. International Journal of
Science Culture and Sport. 2015;3(Special Issue 3):479-488

Badan Pusat Statistik (BPS). (2018). Kota Semarang Brianne A. Bruijns, Kristi B. Adamo, Shauna M. Burke, Valerie Carson, Jennifer D. Irwin, PattiJean Naylor, ..., Brian W. Timmons, Leigh M. Vanderloo, Patricia Tucker. (2019). Exploring the physical activity and screen-viewingrelated knowledge, training, and self-efficacy of early childhood education candidates. $B M C$ Pediatrics. 2019;19(1):1-13

Heru Santoso W. N (2013). Petunjuk Praktis Denver Developmental Screening Test, Jakarta: Buku Kedokteran EGC 21 Hurlock, E. B. (1980). Psikologi Perkembangan (Suatu Pendekatan Sepanjang Rentang Kehidupan), edisi kelima. Jakarta: Penerbit Erlangga.

Ladru Danielle Ekman, Gustafson Katarina. (2018). „Yay, a downhill!": Mobile preschool children"s collective mobility practices and „doing" space in walks in line. Pedagogický Časopis. 2018;9(1):87-107

Nugroho. HSW. (2009). Denver Development Screaning Test. Jakarta: Buku Kedokteran EGC Rahyubi. 2012. Teori Belajar dan Aplikasi Pembelajaran Motorik. Bandung: Nusa Media Siti Nur Solikah, Saka Suminar. (2017). Pengaruh Pemberian Bedong Terhadap Perkembangan Motorik Bayi usia 3 Bulan. Unnes Journal of Public Health. 2017;6(3):203-208 